\title{
SOCIO-ECONOMIC DETERMINANTS OF CONTRIBUTIONS OF TIMBER MARKETING TO INCOME OF TIMBER MERCHANTS IN BODIJA SAWNWOOD MARKET, IBADAN, NIGERIA BY
}

Gbenga Lawrence Alawode and Saka Oladunni Jimoh

Department of Social and Environmental Forestry, University of Ibadan, Nigeria.

\begin{abstract}
Forest enterprise has been identified as a means of generating income among people; plays a vital role in enhancing the quality of life of forest-dependent people. Despite the opportunities timber marketing offers the people, the disparities in the income generation of the marketers in the Bodija sawn wood Market and the effect of socioeconomic factors on income generation of the marketers is not well understood. This study was conducted to assess the socio-economic determinants of contributions of timber marketing to the income of timber merchants in Bodija sawn-wood Market. One hundred structured questionnaires were administered randomly in five zones of the sawn wood Market to obtain information on the socio-economic background of the sawn wood marketers and the contribution of timber trade to their incomes. The result indicated that $99.0 \%$ of the respondents were male while females constituted $1.00 \%$. Seventy-five percent of the marketers had post-primary education and $25 \%$ had primary education. Two percent of the marketers had below 10 years of marketing experience, twenty-six percent had between 11 and 20 years, 57.00\% had between 21 and 30 years, and $15.00 \%$ had more than 30years experience. Fifty-eight percent of the respondents earned between $\$ 10000$ - $\$ 60000$ (1US\$ = 360.00) from timber marketing, thirty-one percent earned between $\$ 60001$ and $\$ 110000$, 7\% earned between $\$ 110001$ and $\$ 160000$, while $4 \%$ earned above $\$ 160000$ per month. Chi-square analysis of the socioeconomic characteristics of the respondents and income generation at $\alpha$ level of 0.05 indicated that ethnicity (0.001) and years of experience (0.009) significantly influenced income while the level of education (0.101), age (0.122), and religion (0.745) had no significant influence on the incomes of marketers. Experience is an important factor in sawn wood marketing and a major determinant of the contribution of timber marketing to the income of timber marketers in Bodija sawn wood Market.
\end{abstract}


Keywords: Sawn wood, Socio-economic, Timber marketing, Forest enterprise

\section{INTRODUCTION}

Timber plays a significant role in the socio-economic development of Nigeria (Usman and Adefalu, 2010). Before the discovery of oil in the late 50s and early 60s, the agriculture sector (forestry inclusive) was the mainstay of the Nigerian economy, contributing over 80 percent of the GDP (Idumah and Awe, 2017). Over the years, the level of contribution has dwindled due to the undue reliance on oil. However, the subsector plays a major role in providing industrial raw materials (timber) and providing income as well as preserving biodiversity (Odetola and Etumnu, 2013).

The benefits from timber range from its usefulness for interior and exterior decorations in homes and industries, production of electric poles, plywood, pulpwood, veneers, and planks needed by building and construction industries (Adebara et al., 2014). Timber, therefore, impacts the rest of the economy by making positive contributions to raw material production and supply for construction, furniture making and packaging (Larinde, 2010).

Forest enterprises have been considered as a means of generating income among people that depend on forest in Nigeria (Aiyeloja et al., 2013). When poverty reduction is considered solely in terms of income generation, small forest enterprises may or may not compare favourably with large enterprises (Macqueen et al., 2007). However, when a multitude of dimensions of well-being are considered, small forest enterprises are seen to have a vital role in enhancing the quality of life of forest-dependent people and lifting them out of poverty (IIED, 1996; Egid, 2010).

The marketing of timber is an enterprise that gives opportunities to people within the society to meet their needs and it supports different people from different levels on the social strata (Famuyide et al. 2012). However, there has been observed disparities in income generation among timber Marketers in Bodija sawn wood Market. Various factors may influence the income-generating potentials of timber marketers. Years of experience and marital status have been identified by Adedokun et al. (2017) to affect income generation. There have been studies on the socio-economic characteristics of timber marketers (Aremu et al. 2015) and their influence on market and marketing information (Ajewole and Fasoro, 2013). However, there is limited information on the socio- 
economic factors that influence plank marketers' income generation in Bodija sawn wood Market.

This study, therefore, provides baseline information on the socio-economic characteristics of the marketers in Bodija sawn-wood Market as well as how these characteristics influence the income derived from timber marketing. The information will allow current and prospective marketers to increase their income generation from the marketing of sawnwood.

\section{METHODOLOGY}

The study was conducted in Bodija Sawn Wood Market in Ibadan, Oyo State, Nigeria. Bodija Market is located between Longitudes $3^{\circ} 54^{\prime} 56^{\prime \prime E}$ and $3^{\circ} 55^{\prime} 12$ "E; and Latitudes $7^{\mathrm{O}} 26^{\prime} 2^{\prime \prime} \mathrm{N}$ and $7^{\mathrm{O}} 26^{\prime} 16^{\prime \prime} \mathrm{N}$ (Figure 1). It is the largest sawn wood market in Ibadan and covers more than 10 hectares of land (Aremu et al., 2015). It is part of the large Bodija Market, one of the busiest and heavily populated places in Ibadan (Filani, 2005). Ibadan is located in southwestern Nigeria but in the southeastern part of Oyo State. Ibadan is noted for the concentration of timber and non-timber products markets with the associated sawmills in different locations (Olugbire et al., 2015).
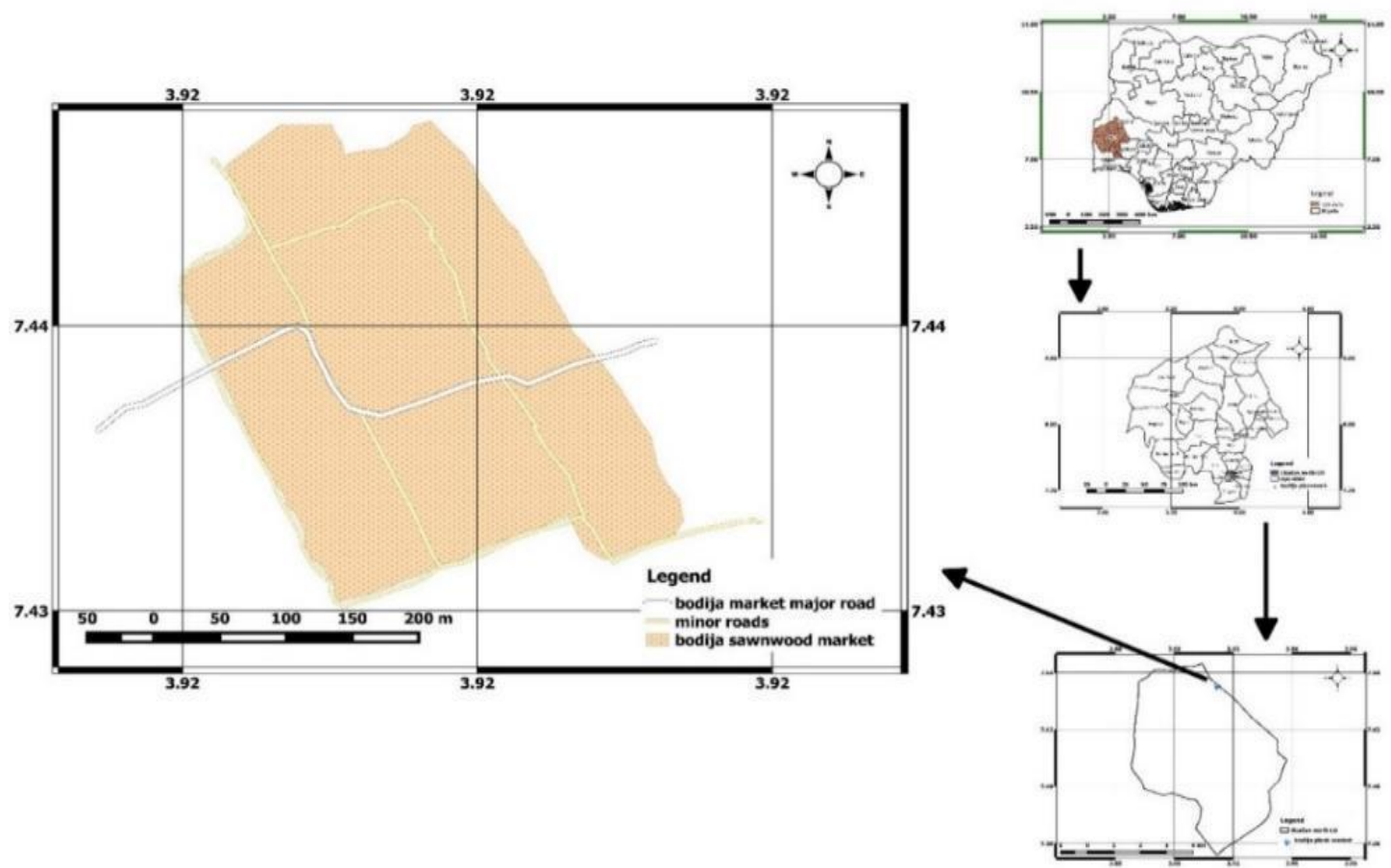

Figure 1: Map of Bodija sawn wood Market

\section{Data collection and analysis}

Primary data was collected using structured questionnaires administered to selected timber marketers in Bodija sawn wood Market. The market is made up of nine zones. 
Adopting the methodology of Ajewole and Fasoro (2013), five zones were selected randomly out of the nine zones that make up the sawn wood Market. In each selected zone, 20 respondents were randomly selected. Thus, one hundred questionnaires were administered to obtain information on

Before questionnaire administration, a pre-test involving 10 respondents was carried out in the study area. The questionnaire was revised based on the result of the pre-test as recommended by Ham (2007).

Descriptive statistics and Chi-square analyses were used to determine the relationship between the socio-economic characteristics of respondents and contributions of timber marketing to income (Keller and Warrack, 2003).

\section{RESULTS}

\section{Age distribution of the respondents}

Table 1 shows that $52 \%$ of the timber marketers were between 41 and 50 years of age. This finding shows that marketers are largely of middle age. This may be as a result of the time required to learn the rudiments of the trade. Twenty-one percent were between the age group of 20-40 years, and $27 \%$ were over 50 years old. The minimum age of the marketers was 22 years and the maximum age was 84 years. The mean age was 47 years. This indicates that middle-aged people are more engaged in sawn wood marketing than the aged and younger ones in the study area. With middle-aged people dominating the market, it enables them to cope with the stressful nature of the work as well as allowing them to be able to take the risk. It also helps them to explore new ideas and be open to improved technologies which will improve their daily activities and thus contribute positively to income generation from timber marketing. This is in agreement with Aremu et al. (2015), who reported that the sawn wood market is dominated by young and middle-aged marketers in the study area. Also, the age distribution agrees with Sekumade and Oluwatayo (2011), who stated that markets with young and active people have the potential of thriving better because of their ability to take risks.

\section{Level of education of the respondents}

Table 1 shows that all the respondents are literate. Respondents with primary education account for $25 \%$, secondary education accounts for $64 \%$, and tertiary education accounts for $11 \%$. The majority of the respondents were secondary school certificate holders. 
Thus, education is not a prerequisite for venturing into the business, although it could serve as an added advantage to those with it. This is in line with Adedokun et al. (2017) who asserted that level of education does not influence the marketing of timber, although it might aid productivity and better management. Education is key to the adoption of innovations by marketers (Achoja and Okoh, 2014). Hence, the marketers will readily learn and accept new technologies which will improve their marketing abilities and thus increase their revenue generation and profit maximization in timber marketing. This view is supported by Ajewole, (2005), Etim et al. (2012) and Faleyimu (2014) who asserted that formal education has advantages over the deficiency in non-formal education and could positively influence the adoption of innovation and increase the level of awareness and perception of individuals and groups. Haruna et al. (2012) also reported that literate traders adopted new marketing ideas faster than illiterates and would find it relatively easier in their dealings with people, more especially in the exchange process.

\section{Respondents' Experience}

As shown in Table 1, respondents' years of experience varied greatly. Fifty-seven percent of the respondents had 21-30 years of experience, 26.0\% had 11-20 years of experience, $15 \%$ had more than 30 years of business experience, and 2.0\% had 1-10 years of experience. The difference shows a variation in startup time. It also shows that there is no restriction to entry and exit as the market operates a free market economy. Also, marketing experience is a vital attribute that prospective sawn wood marketers must put into consideration before venturing into the business. This will help to gain insight into the nitty-gritty of the trade as well as the activities involved to reap the full benefits of one's investment. This confirms Busari et al. (2012) and Aremu et al. (2015), both of whom asserted that experience is a vital skill necessary to overcome factors that threaten both producers' and marketers' returns on their investments.

\section{Sex, Ethnicity and Religion distribution of the respondents}

Table 1 reveals that Bodija sawn wood Market is dominated by the male, who accounts for 99\% of respondents. This may be as a result of the stressful nature of the business and the lack of modern technologies for the transferring of planks from one area to another. This is in line with Ndaghu et al. (2011), who stated that livelihood activities, where hard labour is demanded, is always dominated by male. Hence, they can cope effectively with 
the stress that comes with the timber trade and engage in activities that will increase income generation.

The sawn-wood market is dominated by the Yorubas. This may be due to the geographical location of the market. The market is located in the southwestern part of Nigeria which is dominated by Yorubas. Engaging in a business transaction with people of the same ethnicity will increase communication between both the buyers and sellers and thus allows for profit maximization and cost-effectiveness for the sellers and buyers respectively. Also, the presence of an Igbo respondent revealed the possibility for people of other ethnic backgrounds to transact their businesses in the market. The result also shows that the two predominant religions in Nigeria can be found in the market. Hence, the market is made up of more than one religion.

Table 1: Socio-economic characteristics of respondents

\begin{tabular}{lll}
\hline Variables & Frequency & Percentage \\
\hline Age & 3 & 3 \\
$20-30$ & 18 & 18 \\
$31-40$ & 52 & 52 \\
$41-50$ & 27 & 27 \\
$>50$ & 100 & 100 \\
Total & & \\
Level of education & 25 & 25 \\
Primary & 64 & 64 \\
Secondary & 11 & 11 \\
Tertiary & 100 & 100 \\
Total & & \\
Years of Experience & 2 & 2 \\
$1-10$ & 26 & 26 \\
$11-20$ & 57 & 57 \\
$21-30$ & 15 & 15 \\
$>30$ & 100 & \\
Total & & \\
Sex & & \\
Male & & \\
\hline & & \\
& 29 & \\
\hline
\end{tabular}




\begin{tabular}{lll} 
Female & 1 & 1 \\
Total & 100 & 100 \\
Religion & & \\
Christianity & 17 & 83 \\
\cline { 2 - 3 } Islam & 83 & 170 \\
Total & 100 & \\
Ethnicity & & 99 \\
Yoruba & 99 & 1 \\
Igbo & 1 & 100 \\
Total & 100 & \\
\hline
\end{tabular}

Source: Field survey (2019)

\section{Net Monthly income from sales of sawn wood}

From table 2, 58\% of the respondents earned between 10,000 and 60,000 monthly, $31 \%$ earned between $\$ 60,001$ and $\$ 110,000,7 \%$ earned between $\$ 110,001$ and $\$ 160,000$ and $4 \%$ of the total respondents earns monthly income above $\$ 160,000$. The lowest monthly income realized among the respondents from the sales of sawn wood is $\$ 10,000$ while it is also possible to earn as much as $\$ 300,000$ with the mean income standing at $\$ 69,830$ (Table 2). The frequency distribution reveals that only $1 \%$ of the respondents earns below the national minimum wage which currently stands at $\$ 30,000$. Hence, the sawn-wood business is relatively a profitable one considering the horizon within which the economy of the country operates and it contributes about 99\% of the total income of the respondents. This agrees with Adedokun et al. (2017) who asserted that timber marketing is profitable enough to be relied upon to cater for both larger and smaller households.

Table 2: Net monthly income from sales of sawn wood

\begin{tabular}{ll}
\hline Variables & Frequency \\
\hline Estimated income from timber sales ( $¥)$ & \\
$10000-60000$ & 58 \\
$60001-110000$ & 31 \\
$110001-160000$ & 7 \\
$>160000$ & 4 \\
Total & 100 \\
\hline
\end{tabular}


Mean

69830

Minimum

10000

Maximum

300000

Source: Field survey (2019)

Note: 1US \$ = N360.00 at the time of study

\section{Relationship between socio-economic characteristics of respondents and income generation}

From table 3, Spearman's correlation value of 0.122 at $\alpha=0.05$ revealed that there is no significant relationship between the age of respondents and the income generated from the sales of timber products. For the relationship between years of experience and income, there is a positive correlation. Spearman's correlation value of 0.009 at $\alpha=0.05$ shows that there is a significant relationship between the years of experience of respondents and the income generated from the sales of timber products.

Pearson's Chi-square $\left(\mathrm{x}^{2}\right)$ analysis value of 0.101 at $\alpha$ level of 0.05 showed that the respondents' level of education has no significant effect on the income generated.

Also, Pearson's Chi-square $\left(\mathrm{x}^{2}\right)$ analysis value of 0.001 at $\alpha$ level of 0.05 showed that there is a significant relationship between ethnicity and income.

Table 3: Relationship between socioeconomic characteristics and income of respondents

\begin{tabular}{ll}
\hline Socio-economic characteristics & sig. at 0.05 \\
\hline Age & $0.122^{\mathrm{ns}}$ \\
Years of experience & $0.009^{*}$ \\
Religion & $0.745^{\mathrm{ns}}$ \\
Level of education & $0.101^{\mathrm{ns}}$ \\
Ethnicity & $0.001^{*}$ \\
\hline
\end{tabular}

Source: Field survey (2019)

\section{DISCUSSION}

The income derived by individual marketers is independent of the age of the respondents, but experience has been found to affect income generation. Hence, the more the 
experience, the more income generated from this business. Thus, for the full benefits of this business to be realized, individuals need to get accustomed to the various operations within the market and also those operations that are outside the market but have an impact on the market; and acquire necessary experience in the area of demand and supply of various timber products within the market. This finding is in agreement with Busari et al. (2012), and Aremu et al. (2015), who observed that experience is a very important skill required to overcome factors that affect both producers' and marketers' returns on their investment.

Although education can serve as an added advantage to individuals in such ways as access to information and trends in demand and supply of the product; this does not necessarily translate to high revenue generation. As asserted by Haruna et al. (2012), literate traders have been found to adopt new marketing ideas faster than illiterates and would find it relatively easier in their dealings with people more especially in the exchange process but these dealings will not necessarily translate to an increase in revenue generation.

The market is dominated by Yoruba people and is also located within the southwestern region of this country. This implies that the majority of the customers are from Yoruba ethnicity and when the same tribe bargain for a particular product, there is a flow of communication between both the buyer and the seller and will, in turn, allow both parties to maximize their profits. On the other hand, communication between individuals of different ethnicity might be truncated as a result of the language barrier and influence sales and revenue generation.

\section{Conclusions}

From the results obtained from this study, experience is vital to the business of sawn wood marketing as it has been found to have a significant influence on the income generation of timber marketers in Bodija sawn wood Market. Also, owing to the geographical location of the market, ethnicity has been found to influence the contribution of timber marketing to the income of the marketers in the study area.

\section{Recommendations}

Individuals planning to engage in the business should acquire the necessary knowledge from experienced people in the business. Training in the areas of digital and online marketing, customer relation and so on, should be organized among the marketers to enable them to keep up to date with various practices that will enhance their knowledge about the marketing of timber and timber products. In addition, government interventions 
should make use of marketers' experience, by making them major stakeholders in decisions making process, for such intervention to be meaningful. Also, policies in the market should be channelled towards those that will improve the marketing knowledge of the marketers. Finally, further studies should be carried out on the role of invested capital on income generation in the study area. 


\section{REFERENCES}

Achoja, F O, Okoh, R.N. (2014). Post-Harvest Properties of Tomato and Effect on Its Marketing Efficiency. Turkish Journal of Agricultural and Natural Sciences 1(1): 52-58.

Adebara S. A, Hassan A, Shitu M. B, Anifowose M. A. (2014). Quality of utilization of timber species for building construction in Minna Nigeria. The International Journal of Engineering and Science. Vol 3(5):46-50.

Adedokun, M. O., Ojo, T.M. and Dairo, G.S. (2017). Economic Importance and Marketing of Timber Species in Oyo Town. International Journal of Scientific \& Engineering Research Volume 8, Issue 11, pp 263-272

Aiyeloja, A.A., Oladele, A.T. and Furo, S.B. (2013). Sustaining Livelihood through Sawnwood Marketing in Port Harcourt, Nigeria. International journal of science and nature 4(1): 84-89.

Ajewole, O. I. and Fasoro, O. (2013). Market and marketing information of Bodija plank market in Ibadan metropolis, Ibadan, Oyo State, Nigeria. Nigerian Journal of Forestry 43(1) 13-19, 2013

Ajewole, O.I (2005): Social and Institutional Determinants of Urban Forestry Development in Lagos. An Unpublished PhD Thesis. Submitted to the Department of Forest Resources Management, University of Ibadan. 206pp.

Aremu, F.J, Olugbire, O.O, Adebayo, D.A and Apata, O.V. (2015). Socio-Economic Characteristics of Bodija Sawn Wood Market in Ibadan, Oyo State, Nigeria. Journal of Social Sciences and Public Policy, 7(2): 94-103

Busari, A O. Idris-Adeniyi, K.M. Oyekale, J.O. (2012). Economic Analysis of Vegetable Production by Rural Women in Iwo Zone of Osun State, Nigeria. Greener Journal of Agricultural Sciences. Vol. 3 (1), pp. 006-011

Egid, F. N. (2010). Influence of timber trading on poverty reduction in Mufindi district, Iringa region, Tanzania. a dissertation submitted in partial fulfilment of the requirements for the degree of master of arts in rural development. Sokoine University of agriculture. Morogoro, Tanzania.

Famuyide, K.M., (2012). Timber species availability and Variation in Ibadan and Oyo Timber Markets over the last forty years, Elixir Bio Diver. 49 (2012) 10131 10136 
Filani, M.O. (2005). Transport Market Study; The Bodija Cattle Market in Ibadan. Paper presented at Department for International Development, United Kingdom.

Haruna, U., Sani, M. H., Danwanka, H. A. and Adejo, E. (2012). Economic Analysis of Fresh Tomato Marketers in Bauchi Metropolis of Bauchi State, Nigeria. Nigerian Journal of Agriculture, Food and Environment. 8(3):1-8

Idumah, F.O. and Awe, F. (2017). Contribution of Timber Exports to Economic Growth in Nigeria: An Econometric Analysis. Journal of Research in Forestry, Wildlife \& Environment Vol. 9(4) December 2017

IIED, (1996). Towards a sustainable paper cycle. For the World Business Council for Sustainable development by the International Institute for Environment and Development, London, UK. 63pp.

Keller, G., and Warrack, B. (2003). Statistics for management and economics, 6th edition.

Curt Hinrichs publisher, Pacific Grove, CA 93950, USA: pp 350.

Larinde S.L. (2010). Secondary Wood Processing and the Nigeria Sawmill Industry: Issues, challenges and opportunities. In: Readings in sustainable tropical management, essays in honour of Professor Popoola, Labode. (ed) Adeyoju, S. K, Bada, S. O. Zenith Book House, Bodija-Ibadan. 2010; 283

Macqueen, D., Dufey, A. and Patel, B. (2007). Exploring fair trade timber: a review of issues in current practice, institutional structures and ways forward. International Institute for Environment and Development, London. [http://www.iied.org/NR/forestry/projects/fairtradetimber.html].

Ndaghu, A.A, Taru, V.B, Tizhe, I and Tizhe, J. (2011). Analysis of Socio-economic Characteristics of Fuel Wood Marketers in Yola Metropolis, Adamawa State, Nigeria. J Hum Ecol, 36(2): 153157

Odetola and Etumnu, (2013). Contribution of Agriculture to Economic Growth in Nigeria. The 18th Annual Conference of the African Econometric Society (AES) Accra, Ghana at the session organized by the Association for the Advancement of African Women Economists (AAAWE), 22nd and 23rd July 2013

Olugbire, O. O, Aremu, F. J, Ayomide, A. A, Olawale, O. O. (2015). Structure, Conduct and Performance of Sawn Wood Market in Ibadan, Oyo 
Sekumade, A. B, Oluwatayo, I. B (2011). Economic Analysis of Plank Production in Gbonyin Local Government Area of Ekiti State, Nigeria. International Journal of Agricultural Economics \& Rural Development. 4 (1)

Usman B. A, Adefalu L. L. (2010). Nigeria forestry, wildlife and protected areas: Status report. Tropical Conservancy. Biodiversity II (3\&4) 